IZA DP No. 3922

Return Migration and Occupational Choice

Matloob Piracha

Florin Vadean

J anuary 2009 


\title{
Return Migration and Occupational Choice
}

\author{
Matloob Piracha \\ University of Kent \\ and IZA \\ Florin Vadean \\ University of Kent
}

\section{Discussion Paper No. 3922 \\ January 2009}

IZA
P.O. Box 7240
53072 Bonn
Germany

Phone: +49-228-3894-0

Fax: +49-228-3894-180

E-mail: iza@iza.org

\begin{abstract}
Any opinions expressed here are those of the author(s) and not those of IZA. Research published in this series may include views on policy, but the institute itself takes no institutional policy positions.

The Institute for the Study of Labor (IZA) in Bonn is a local and virtual international research center and a place of communication between science, politics and business. IZA is an independent nonprofit organization supported by Deutsche Post World Net. The center is associated with the University of Bonn and offers a stimulating research environment through its international network, workshops and conferences, data service, project support, research visits and doctoral program. IZA engages in (i) original and internationally competitive research in all fields of labor economics, (ii) development of policy concepts, and (iii) dissemination of research results and concepts to the interested public.
\end{abstract}

IZA Discussion Papers often represent preliminary work and are circulated to encourage discussion. Citation of such a paper should account for its provisional character. A revised version may be available directly from the author. 


\section{ABSTRACT}

\section{Return Migration and Occupational Choice*}

This paper explores the impact of return migration on the Albanian economy by analysing the occupational choice of return migrants while explicitly differentiating between selfemployment as either own account work or entrepreneurship. After taking into account the possible sample selection into return migration, we find that the own account workers have characteristics closer to non-participants in the labour market (i.e. lower education levels), while entrepreneurship is positively related to schooling, foreign language proficiency and savings accumulated abroad. Furthermore, compared to having not migrated, return migrants are significantly more likely not to participate in the labour market or to be entrepreneurs. However, after a one year re-integration period, the effect on non participation vanishes and that on entrepreneurship becomes stronger. As for non-migrants, the migration experience would have increased their probability to be entrepreneurs showing the positive impact of migration on job creating activities in Albania.

JEL Classification: $\quad$ C35, F22, J24

Keywords: occupational choice, return migration, sample selection

Corresponding author:

Matloob Piracha

Department of Economics

University of Kent

Canterbury, Kent CT2 7NP

United Kingdom

E-mail: M.E.Piracha@kent.ac.uk

\footnotetext{
* We would like to thank Alan Carruth, Don DeVoretz, Amanda Gosling, Johannes Jutting and participants at the research seminar of the Department of Economics, University of Kent, third IMISCOE conference on Migration and Development in Albania and the Western Balkans, Durres and $55^{\text {th }}$ North American Regional Science Council conference, New York, for helpful comments on earlier versions of the paper. An earlier version was part of a report for the "Managing Labour Migration to Support Economic Growth" project coordinated by the OECD Development Centre, whose financial support is gratefully acknowledged. The usual disclaimer applies.
} 


\section{Introduction}

Many studies in economics focus on analysing whether return migration and remittances are economically beneficial for emigration countries. Returning migrants are assumed to bring with them additional human capital, while migrants' remittances often help to ease poverty and provide a means of investment in small and medium size businesses in the presence of capital constraints. Consequently, return migration and remittances are perceived to have an important potential for promoting growth and development, which prompted policymakers in both migrant host and home countries to encourage efforts to understand and facilitate return/circular migration, channel a bigger share of remittances through the formal financial systems, as well as encourage their use for productive investment (see Dayton-Johnson et al., 2007; World Bank, 2005).

This paper adds to the existing literature by analysing the impact of migration on Albania's labour market by looking at the economic activities of return migrants. Recent research on the occupational choice of return migrants has tried to explain the propensity of returnees to become self-employed. The arguments used are, for example, the role of remittances and repatriated savings in overcoming capital constraints (Ilahi, 1999; Mesnard, 2004) and the accumulation of human capital (i.e. business skills and ideas) through exposure to the host country's market economy environment (McCormick and Wahba, 2001; Dustmann and Kirchkamp, 2002).

A key element missing from the existing literature is the distinction between different types of self-employment. This distinction is important since working on own account is likely to have a weaker direct impact on employment (and hence growth) compared to entrepreneurship. In this paper, therefore, we study the occupational choice of return migrants by explicitly differentiating between the propensities of returnees to become self-employed as own account workers (i.e. without having any paid employees) and as entrepreneurs (i.e. owners of larger firms with paid employees). We do this by allowing the choice of employment to be made from four occupational alternatives: non participation, wage employment, own account work and entrepreneurship.

The consideration of the other occupational alternatives has policy relevance as well. Considering that they earn abroad and consume in Albania, return migrants not participating in the labour market could have a marginal positive impact on the economy, at least at the regional level, as long as the increased demand is met by an 
increase in production capacities and/or output. However, if the local production capacities fail to adjust, the increased demand might generate inflation and/or have an adverse effect on the current account (see World Bank, 2005). Wage employees could have a positive effect on labour markets too, if they meet shortages that hinder the development of the economy and/or bring with them additional skills accumulated abroad. Therefore, our main research questions are: How does migration affect the occupational choice of returnees? How is the aggregated effect on self-employment divided between own account work and entrepreneurship? Which of these two effects is stronger? What are the differences in characteristics among returnees in the various occupational groups and how do these differ compared to non-migrants?

After taking into account the possible sample selection into return migration, we find that, in Albania, own account workers have characteristics closer to the nonparticipants in the labour market (i.e. lower education levels), while entrepreneurship is related to secondary and tertiary education levels, proficiency in Italian (i.e. the language of Albania's main trading partner) and target saving migration. Albanian own account workers, irrespective of their past migration experience, have lower average incomes compared to both entrepreneurs and wage employees, indicating that they are rather a marginalised group. Nevertheless, our results show that with the time spent in Albania after return, permanent returnees opting for non participation or own account work do re-integrate into the labour market and find a way into paid employment, confirming Harris-Todaro’s “parking lot” hypothesis. ${ }^{1}$

Furthermore, our results provide some reconciliation for the divergent empirical findings with respect to the characteristics of self-employed returnees. For example, McCormick and Whaba (2001) found evidence that self-employed returnees in Egypt are literate but with a low education level. Similarly, results of Ilahi (1999) show that higher skilled returnees to Pakistan exhibit a greater propensity for wage employment over self-employment as they command higher wages in the labour market. He argues that unskilled workers are often left outside the labour market and choose to engage in own account activities that do not require labour market skills, e.g. small trade or workshops. On the other hand, Dustmann and Kirchkamp (2002) and Radu and Epstein (2007) found a positive relationship between schooling and self-employment activities

\footnotetext{
${ }^{1}$ According to dualist and Harris-Todaro models of labour markets in developing countries, in the absence of sufficient employment opportunities in the formal sector, small (and often informal) selfemployment activities are used to bide time by those aspiring to move into formal employment (Harris and Todaro, 1970).
} 
in the case of return migrants to Turkey and Romania respectively, and explain this by the fact that education may have a positive effect on the returns to self-employment activities and, therefore, increase the probability of higher skilled returnees to choose this option. A priori, such a positive relationship between schooling and selfemployment is more likely to be present in the case of entrepreneurs rather than own account workers.

The remainder of the paper is structured as follows. The next section gives an overview on the developments in the Albanian labour market that led to international migration, return migration and occupational structure to which our data refers. Furthermore, it gives some stylised facts on the occupational choice of non-migrants and return migrants. Section 3 presents the empirical approach while section 4 discusses the results. Concluding remarks appear in the final section.

\section{Background and Data}

Since the fall of the Iron Curtain, Albania has become a country of mass emigration. It is estimated that at any given time more than 25 percent of its population lives abroad, which is by far the highest proportion amongst the Central and East European countries. Although Albanians have migrated to several countries around the world including USA, Canada, Australia and a number of EU countries, the biggest two recipients of Albanians have been by far Greece and Italy. Estimates suggest that Greece and Italy together account for approximately 80 percent of the migrants, with Greece as the leading destination because of its geographical proximity (Vullentari, 2007).

One of the main reasons for migration is for employment opportunities, with the majority of those who were unemployed in Albania (53 percent) intending to migrate for a short spell abroad (European Training Foundation, 2007). The main push factor for migration is the lack of demand for labour, particularly in the formal sector, which has forced people to start their own income-generation activities. However, in the presence of credit constraints and the lack of entrepreneurial abilities this is not always possible. Hence migration serves two purposes: to obtain gainful employment, which could contribute directly or indirectly towards human capital accumulation ${ }^{2}$ and/or to raise

\footnotetext{
${ }^{2}$ Direct acquisition could be through formal training in vocational programmes whereas indirect training could be ideas picked up from working in a market economy.
} 
financial capital from higher wage income abroad in order to start up a business upon return.

Return migration in Albania is a relatively recent phenomenon. According to estimates, over 70 percent of the returnees came back to Albania after 2001, when the socio-economic and political situation started to improve (ETF, 2007). Own estimates show that return migration is an important phenomenon - about $1 / 3$ rd of the individuals who migrated after 1990 returned by 2005 - and hides different realities too. Almost 50 percent of the returnees expressed their intention to re-migrate, while the other half intending to resettle permanently.

The dataset used is the 2005 Albanian Living Standards Measurement Survey (ALSMS), a survey conducted by the Albanian Institute of Statistics (INSTAT) with technical support from the World Bank. The data is based on a representative survey of 3,640 households (17,302 individuals) and contains detailed information about the individual characteristics (e.g. gender, age, education, occupation, income [if working], and migration history), household characteristics (e.g. subjective economic status, marital status, number of children), community and regional characteristics (e.g. regional location; rural/urban location; access to banking, electricity and piped water) and non-farm business activity (e.g. type of business, employment of household and non-household labour).

The individual's main occupation is self reported and contains the following categories: 1) employee of someone who is not a member of the household; 2) paid worker in household farm or non-farm business of a household member; 3) employer/entrepreneur; 4) worker on own account; and 5) unpaid worker in a household farm. We merged the first two categories under "wage employee” and excluded from the sample the unpaid workers on household farms (i.e. 459 observations). ${ }^{3}$

A migrant is defined as a person who migrated abroad for at least one month, for non family visits, since turning age 15. Migration from Albania is predominantly male: only about 6.5 percent of the return migrants are female, confirming evidence from a recently conducted survey by the European Training Foundation (2007). Due to the small sample size and the different participation rates, females are excluded from the

\footnotetext{
${ }^{3}$ Individuals (129 of them) who reported to have an active non-farm business in which they had engaged other household members and/or hired non-household employees were considered "Employers" even if declared not working, being an own account worker or an unpaid worker in a household farm. Similarly, 13 individuals having an active business with no paid employees and no other household members engaged in the business were considered own account workers even if declared not working, being an employer or an unpaid worker in a household farm.
} 
analysis. After excluding also all observations with missing values for the variables included, the sample contains 962 return migrants, representing about 32 percent of the male potential labour force aged 20 to 64 (i.e. 3,011 males). ${ }^{4}$

Return migrants are on average five years younger than non migrants, significantly less educated (i.e. the tertiary education rate is 7.0 percentage points lower and the primary education rate 6.5 percentage points higher), and unsurprisingly significantly more likely to speak Italian or Greek, the languages of the two main destination countries (see Table 1). In terms of occupation, return migrants have a relatively higher non participation rate (+5.8 percentage points), most likely due to the important number of circular/seasonal migrants in the returnees' group (e.g. 36 percent of the returnees expressed their intention to migrate again). These migrants often work abroad in the harvest, holiday and/or construction season and spend the rest of the year at home, consuming from the savings accumulated. On the other hand, return migrants are significantly less likely to participate in wage employment (-5.5 percentage points) but their entrepreneurship rate is about 45 percent higher compared to non migrants (7.9 percent vs. 5.4 percent respectively).

We also note the high own account working rate (i.e. over 20 percent) for both population groups. Using an argument from Ilahi (1999), the failure of the Albanian economic system to create enough productive employment might have left an important part of the workforce outside the labour market. In developing countries like Albania, many unskilled workers in this situation choose to engage in self-employment activities that do not require labour market skills, for instance small retail trading or small workshops. Moreover, in transition countries land reform legislations in the early 1990s caused subsistence farming to become a "parking-lot" for certain categories of workers who lost their jobs in the non-agricultural sector (Voicu, 2002).

The household subjective economic status of return migrants in 1990 is slightly but significantly lower compared to that of non migrants (3.55 vs. 3.80 respectively) ${ }^{5}$, pointing to evidence that individuals from relatively poorer households have used migration as a strategy to improve their standard of living. And it seems that they have succeeded to catch up: both their subjective economic status and their average monthly income (if working) are statistically similar to non migrants in 2005.

\footnotetext{
${ }^{4}$ By potential labour force we mean a person who is not enrolled in education, not handicapped, and not in military service.

${ }^{5}$ A separate question is asked in the ASLMS 2005 data about the subjective economic status in 1990. The household subjective economic status is self-assessed on an index scale from $1=$ =poor to $10=$ =rich.
} 
Regionally, return migrants are more likely to be located in the Coastal and Central region, the main sources of temporary migration to Italy and Greece. Moreover, return migrants are significantly less likely to be located in urban areas (-12.1 percentage points) compared to their non-migrant counterparts.

When differentiating between the characteristics of the different occupational groups, we note that for both non-migrants and return migrants, younger age and a low education level are strongly related to not working (see Tables 2 and 3). Moreover, the educational composition of the own account worker group is strikingly similar to those of the non working group, irrespective of the past migration experience. Individuals with secondary/vocational and tertiary education are over-represented in wage employment and entrepreneurship. Furthermore, own account workers are significantly less fluent in foreign languages.

These differences in human capital endowment are reflected in the average monthly incomes. Irrespective of the migration experience, own account workers earn, on average, significantly less compared to both wage employees and entrepreneurs, confirming the "marginalisation" hypothesis. ${ }^{6}$

There are important geographical disparities in occupational choice. While non participants, wage employees and entrepreneurs are mainly based in the urban areas, over 50 percent of the own account workers are in rural areas, illustrating the importance of farming for individuals in this occupational category. Regionally, most of the non participants are located in the poorer Mountain region (33 percent of the non participant non-migrants and 50 percent of the non participant returnees); so are 34 percent of the own account working non-migrants. In the absence of other employment activities in the Mountain region, small self-employment activities seem to be a popular alternative to unemployment, for the individuals unwilling or lacking the means to migrate. On the contrary, the majority of the non-migrant wage employees (35 percent) and non-migrant entrepreneurs (34 percent) are located in the relatively more developed capital city, Tirana. Return migrant wage employees are quite evenly distributed across the country: 27 percent in Tirana, 29 and 27 percent, respectively, in the Coastal and the Central regions, while return migrant entrepreneurs seem to have a clear preference for the Coastal region (43 percent), where the fast growing tourism industry creates attractive business opportunities.

\footnotetext{
${ }^{6}$ The significance in differences between sample means is confirmed by t-tests.
} 
Finally, intention to re-migrate and the return reason also seem to affect the occupational choice of individuals. Majority of the own account workers (65 percent) and entrepreneurs (85 percent) are selected from those who intend to resettle permanently back in Albania. There is, however, an important difference in return reasons between the two self employment groups. While 45 percent of the own account workers have returned because of failing their migration target, majority of the entrepreneurs declared to have returned after having accumulated enough savings in the host country (40 percent; see Table 3).

Returnees not participating in the labour market have returned because of failing their initial migration target (34 percent), due to family reasons (27 percent) or are circular/seasonal migrants (27 percent); with the vast majority intending to re-migrate (65 percent). Most of them do cover their daily expenses during the periods spent in Albania from savings accumulated abroad and, if at all, work only occasionally in Albania.

\section{Empirical Approach}

The occupational choice is assumed to be determined by a pairwise comparison of the indirect utilities of the given alternatives:

- non-participation:

$$
\begin{aligned}
& U_{N}>U_{W}, U_{N}>U_{O}, U_{N}>U_{E}, \\
& \text { - wage employment: } \quad U_{W}>U_{N}, U_{W}>U_{O}, U_{W}>U_{E} \text {, } \\
& \text { - entrepreneurship: } \quad U_{E}>U_{N}, U_{E}>U_{W}, U_{E}>U_{O} \text {, }
\end{aligned}
$$$$
\text { - own account working: } \quad U_{O}>U_{N}, U_{O}>U_{W}, U_{O}>U_{E} \text {, }
$$

were $N, W, O$, and $E$ stand for not working, wage employment, own account working, and entrepreneurship respectively. Such unordered choice settings can be motivated by a random utility model (see Green, 2002). For the $i$ th consumer faced with $k=\{N, W, O, E\}$ choices, the utility of choice $j$ is:

$$
U_{i j}=\beta_{j} x_{i}+\varepsilon_{i j}
$$

where $U_{i j}$ is the indirect utility of choice $j$ for individual $i, x_{i}$ a vector of characteristics which affect the occupational choice, and $\beta_{j}$ a vector of choice-specific parameters. 
Assumptions about the disturbances $\left(\varepsilon_{i j}\right)$ determine the nature of the model and the properties of its estimator. We assume that $\varepsilon_{i j}$ are independent and identically distributed with type I extreme value distribution, which leads to the multinomial logit model (see Green 2002; McFaden, 1973). The probability of choosing alternative $j$ is given by:

$$
\operatorname{Pr}\left(y_{i}=j\right)=\frac{e^{\beta_{j} x_{i}}}{\sum_{k=N, W, O, E} e^{\beta_{k} x_{i}}}
$$

Not all $\beta_{j}$ in eq. (3) are identified and we normalise by setting $\beta_{W}=0$.

One problem when estimating the occupational choice of return migrants is that they might not be a random sample from the total population. Research has documented that emigrants rather self-select, albeit with conflicting results on the nature of selection. For example, Borjas (1989) infers return migration from sample attrition and finds that the least successful foreign-born scientists and engineers seem to leave the United States. In contrast, Jasso and Rosenzweig (1988) found that relatively more successful migrants were likely not to naturalise and thus to leave the US. These conflicting findings are reconciled in Borjas and Bratesberg (1996), in which the authors argue that the direction of self-selection in return migration depends on whether the migrants themselves are originally positively or negatively selected. If immigrants are originally positively selected then return migrants tend to be the lower skilled. If they were negatively selected then the highest skilled from the cohort would return.

The selection problem might occur from the fact that the choice made by returnees with respect to occupation might differ from that of non-migrants due to the fact that they are a self-selected group with regard to unobservable characteristics (e.g. lower risk aversion). Therefore, the higher likelihood of returnees to be entrepreneurs might not be an effect of accumulated business experience or financial capital while abroad, but rather be related to their willingness to take risks that affect both the decision to engage in migration and to start a business.

There are two ways to cope with this sort of bias: to treat it either as an endogeneity problem or as a sample selection problem. Choosing the appropriate model hinges on the way in which return migration is believed to affect the occupational choice after return. 
If the human and financial capital accumulated abroad is assumed to have only an intercept effect on the occupational choice, the bias can be treated as an endogeneity problem. The model can be estimated with the pooled sample of returnees and nonmigrants and migration status is instrumented for, in order to correct for endogeneity. In this model, the coefficients $\beta_{j}$ are, however, restricted to be the same for returnees and for non-migrants.

A second option is to consider the selectivity issue as a sample selection bias. In this case, return migration will have not merely an intercept effect but a slope effect. This means that the effects of individual, household and community characteristics on occupational choice are not the same for migrants and non-migrants, i.e. the coefficients for returnees and non-migrants are not the same, and have to be estimated separately.

Following de Coulon and Piracha (2005), who found that returnees and nonmigrants in Albania obtain different labour market returns to their individual characteristics, we expect the estimated coefficients for returnees and non-migrants to be significantly different. ${ }^{7}$ We test for sample selection bias by using the generalised residual $\left(u_{i}\right)$ of a probit selection equation, proposed by Gourieroux et al. (1987). In a first step, a probit model estimates the selection into return migration:

$$
\operatorname{Pr}\left(m_{i}=1\right)=x_{i} \gamma+z_{i} \alpha+v_{i}
$$

where $m_{i}$ is equal to one if the individual is a return migrant and zero if a non-migrant, and $z_{i}$ exogenous variables that determine the selection into return migration. The generalised residual $\left(u_{i}\right)$ has the form:

$$
u_{i}=\frac{\phi(.)}{\Phi(.)[1-\Phi(.)]}\left[s_{i}-\Phi(.)\right]=\left\{\begin{array}{cc}
\frac{\phi(.)}{\Phi(.)} & \text { for returnees }: s_{i}=1 \\
\frac{-\phi(.)}{[1-\Phi(.)]} & \text { for non - migrants }: s_{i}=0 .
\end{array}\right.
$$

\footnotetext{
${ }^{7}$ We also apply a Chow test to compare the differences in the coefficients of the two groups. First, eq. (3) is estimated with interactions of all right hand side variables with the dummies for non-migrants and return migrants respectively, and allowing each group to have its own intercept. Then, we compare the coefficients of the variables interacted with the non-migrant dummy to that of the return migrant dummy. The null hypothesis of similar coefficients is rejected; the chi-square value of 109.98 being higher than the 95 percent level critical value.
} 
where $\phi($.$) and \Phi($.$) denote the probability density and cumulative distribution$ functions of the standard normal distribution. The generalised residual is then introduced as a right hand side variable in eq. (3) along with the selection variable $\left(m_{i}\right)$ and the vector of characteristics affecting the occupational choice $\left(x_{i}\right)$. A valid test for no sample selection bias is the insignificance of the generalised residual coefficient in the occupational choice model.

Another problem when analysing the occupational choice of return migrants relates to the assumption made about the sequence of the decisions with respect to migration and occupational choice. These assumptions are mainly related to the modelling approach of the return migration decision. An important part of the literature regards migration and return as distinctive optimal residential location plans, with the decision to return taken after a time spent abroad on considerations of relative deprivation, location-specific preferences, differences in purchasing power between host and home countries' currencies, or returns to the human capital accumulated in the host country (e.g. Hill, 1987; Djajic and Milbourne, 1988; Stark, 1991; Raffaelhüschen, 1992; and Dustmann 1995, 1997, and 2003). Moreover, migrants who experience outcomes worse than expected (i.e. do not find job or find a job only at a lower wage than expected) may decide to return as well (Borjas and Bratsberg, 1996). In all these cases, the occupation upon return would either be chosen after migration has already occurred, simultaneous to the decision to return to the home country or even after having returned.

Return migration can, however, be a part of a life cycle plan to accumulate capital for self employment activities. This is often the case when capital constraints in the home economy hinder individuals from starting an enterprise, and migration is used as a strategy to accumulate the needed start up funds (Mesnard, 2004). The choice to be an entrepreneur would be made simultaneous to the decision to migrate and return. Similarly, seasonal migrants might decide from the very beginning to work abroad in the harvest, construction and/or holiday season and for the rest of the year to work on own farms or just consume from the savings accumulated abroad.

To capture these possible simultaneous decisions, we estimate also a model in which the occupational choices of non-migrants are considered alternatives to the occupational choices of returnees: 


$$
\operatorname{Pr}\left(y_{i}=j\right)=\frac{e^{\beta_{j} x_{i}}}{\sum_{k=S N, S W, S O, S E, R N, R W, R O, R E} e^{\beta_{k} x_{i}}}
$$

where $S$ stands for stayers (i.e. non-migrants), with other letters explained above, and $R$ stands for return migrants. Eq. (6) is normalised by setting $\beta_{S W}=0$.

The dynamics among the possible choices in the estimation results of the multinomial logit models (i.e. eqs. 3 and 6) are illustrated by computing odds ratios. The factor change in the odds of outcome $m$ versus outcome $n$ for a marginal increase in $x_{k}$ and the other independent variables in the model held constant is given by:

$$
\frac{\Omega_{m \mid n}\left(\mathrm{x}, x_{k, m \mid n}+1\right)}{\Omega_{m \mid n}\left(\mathrm{X}, x_{k, m \mid n}\right)}=e^{\beta_{k, m \mid n}} .
$$

The effect of migration experience on the occupational choice can be expressed as the difference between the predicted probability of choosing the actual occupation and the counterfactual probability of choosing that occupation, had he had a different migration experience. For the return migrant $R_{i}$ this is given by the difference between the actual probability and the probability of having chosen alternative $j$ had he not migrated:

$$
\begin{aligned}
\Delta_{p r, R i}^{h y p} & =\operatorname{Pr}\left(y_{R i}=j\right)-\operatorname{Pr}\left(y_{R i}=j \mid m_{i}=0\right)= \\
& =\frac{e^{\hat{\beta}_{R} X_{R i}}}{\sum_{k=R N, R W, R O, R E} e^{\hat{\beta}_{k} X_{R i}}}-\frac{e^{\hat{\beta}_{S} X_{R i}}}{\sum_{k=S N, S W, S O, S E} e^{\hat{\beta}_{k} x_{R i}}}
\end{aligned}
$$

where the counterfactual, i.e. the second term in eq. (8), can be simply predicted by applying the coefficients obtained from estimating eq. (3) for the non-migrant's subsample ( $\left.\hat{\beta}_{S}\right)$ to the characteristics observed for the return migrant $R_{i}\left(X_{R i}\right)$.

The effect of a hypothetical migration experience on the occupational choice of the non-migrant $S_{i}$ is given by the difference between the counterfactual probability (i.e. had he decided to migrate and return) and the actual probability:

\footnotetext{
${ }^{8}$ Equations (8) and (9) do not include adjustments for sample selection bias. These were discarded as we didn't find any evidence for selectivity bias (see page 14).
} 


$$
\begin{aligned}
\Delta_{p r, S i}^{h y p} & =\operatorname{Pr}\left(y_{S i}=j \mid m_{i}=1\right)-\operatorname{Pr}\left(y_{S i}=j\right)= \\
& =\frac{e^{\hat{\beta}_{R} X_{S i}}}{\sum_{k=R N, R W, R O, R E} e^{\hat{\beta}_{k} x_{S i}}}-\frac{e^{\hat{\beta}_{S} x_{S i}}}{\sum_{k=S N, S W, S O, S E} e^{\hat{\beta}_{k} x_{R i}}}
\end{aligned}
$$

\section{Estimation Results}

Following de Coulon and Piracha (2005), we conduct tests on the variables that identify the selection into return migration. More precisely, we introduce these variables in the estimation of the occupational choice equation (eq. 3) to check if they are significantly different from zero. If they are significant, we exclude them from the entire model; if they are not significant, we include them in the selection probit (eq. 4) and not in the occupational choice multinomial logit (eq. 3). We consider the number of other family members (i.e., other than the individual being interviewed) who are currently migrants or with the past migration experience as a selection instrument, assuming decreasing migration costs and/or a culture of migration in households with more migrants. We expect the instrument to affect the migration decision and to be uncorrelated with the error term in the occupational choice equation. The instrument's coefficient is significant in the selection equation (chi-squared: 48.62; p-value: 0.000) and insignificant in the occupational choice equations (chi-squared: 3.64; p-value: 0.304) and, thus, we use it to identify the model.

We further test for sample selection bias (see Table 4). The generalised residual from the sample selection probit is not significant in the multinomial logit equation. The chi-squared value of the Wald test is 4.37 and, hence, smaller than the 95 percent critical value. We therefore conclude that the results of the occupational choice equation estimated separately for return migrants and non-migrants do not suffer from selection bias. The estimation results are presented in Table 5.

The results for equation (6), in which the occupations of returnees are considered alternative to the occupations of non-migrants are presented in Table 6. We conduct LR-tests for combining alternatives. The tests show that none of the pairs of alternatives can be collapsed (i.e. the coefficients associated with all given pairs of alternatives are significantly different). The Hausman and Small-Hsiao tests of the independence of irrelevant alternatives (IIA) assumption hold also for all occupational 
subsets. ${ }^{9}$ Finally, we run Hausman tests comparing the results of the separate occupational choice estimations for non-migrants and return migrants (eq. 3) with the estimations of equation (6). The chi-squared values are 47.88 for non-migrants and 42.66 for returnees. Both values are smaller than the 95 percent critical value, confirming that the estimation results are significantly similar.

The factor changes in the odds between the occupational subsets of equation 6 are presented in Table 7. There is a strong relationship between age and occupation in the case of non-migrants. Each additional year increases the odds of being an own account worker compared to a non-participant or wage employee by about 2 percent and the odds of being an entrepreneur versus non-participant or wage employee by 3 to 4 percent. This age pattern is consistent with evidence of higher self-employment rates at the end of the active lifetime, which reflects higher rates of retirement out of wage employment compared to self-employment as well as transitions to self-employment at an older age (Zissimopoulos and Karoly, 2007).

The same relationship would be true also for return migrants. However, the odds ratio for entrepreneurship vs. wage employment is significant only at the 10 percent level. For all occupational subsets, a marginal increase in age decreases the odds of being return migrant vs. non-migrant by 5 to 6 percent, confirming the findings from other studies that migration occurs at a younger age.

There is also quite a strong positive relationship between education level and occupational choice. Having secondary/vocational or tertiary education significantly increases the odds of wage employment and entrepreneurship over non-participation and own account working in the case of non-migrants. In the case of return migrants, having secondary/vocational education significantly increases the odds of being an entrepreneur in comparison to all other alternatives, while having tertiary education increases the odds of wage employment both over non-participation and own account working. Even after controlling for other characteristics, the human capital content of the Albanian own account workers' group is significantly below that of wage employees and entrepreneurs, supporting the "parking-lot” hypothesis.

Using foreign language proficiency as a further control for labour market skills, we find that speaking Italian significantly increases the odds of being an entrepreneur for both non- and return-migrants. With Italy being Albania's main trading partner, this effect is most likely related to activities in the foreign trade and/or the tourism sectors.

\footnotetext{
${ }^{9}$ The results of all tests are available upon request.
} 
Consistent with the existence of capital constraints, the estimated odds ratios imply that the amount of initial wealth positively affects the probability of being self employed over wage employed (Blanchflower and Oswald, 1998). Social capital (proxied by the number of friends) has an effect only on own account working but not on entrepreneurship, probably because it provides only a small amount of cheap labour and financial capital (Sanders and Nee, 1996).

The availability of infrastructure (i.e. banking services) strongly increases the odds of being an entrepreneur in the case of return migrants but does not affect the probability of self-employment as an own account worker. de Mel et al. (2008) observe that for a substantial part of the self-employed in Sri Lanka, the lack of growth from working on own account compared to a small or medium size enterprise is more likely to be due to the lack of entrepreneurial abilities. Nevertheless, for the individuals having the abilities and skills to be entrepreneurs, infrastructure seems to be important for running and developing the businesses.

A slightly counterintuitive result for return migrants, is a positive relationship between the availability of banking services and the odds of non-participation over working as a wage employee or as an own account worker. This is most likely due to the fact that banks are motivated to open new branches in regions with a large international migration rate in order to capture the large remittance flows.

An interesting result is that in Albania self-employment activities in rural areas are more likely to be on own account in the case of non-migrants but as entrepreneur in the case of returnees. This could be evidence that migration through accumulation of human capital and/or overcoming capital constraints help individuals located in rural areas to switch from subsistence farming into entrepreneurial activities.

Compared to being located in Tirana, residing in the less developed Central and Mountain region significantly decreases the odds of participating in the labour market for both non-migrants and migrants. Nevertheless, a Coastal region location, with its expanding tourism industry, significantly increases the likelihood of entrepreneurship over wage employment in the case of return migrants. In the Coastal areas return migrants are even more likely to be self-employed compared to non-migrants. Their exposure to western culture probably helps them to better understand the tastes and expectations of foreign tourists, giving them a comparative advantage over their nonmigrant counterparts in providing tourism services. 
In order to capture eventual differences in occupational choice among different types of returnees, we run estimations of the occupational choice model (eq. 3) with return migrants only, with additional controls for the intention to re-migrate or not (first setting) and the return reason (second setting). In both settings we introduce interactions between the re-migration intention and the return reason respectively with a variable measuring the time spent in Albania since the last return. These interaction terms should capture the reintegration dynamics of return migrants in the home country labour market. The estimation results are presented in Table 8 and the factor changes in the odds for the additional explanatory variables in Tables 9 and 10.

For returnees intending to re-migrate, each additional month spent in Albania after return increases the odds of working on own account both over non-participation and wage employment by about 2 percent (see Table 9). The behaviour is similar to those having returned after the expiry of a temporary/seasonal work permit, indicating that the two groups overlap. The same is true for returnees due to family reasons; their behaviour not being significantly different when compared to seasonal migrants (see Table 10). The limited amount of time repeat/seasonal migrants spend at home prevent them from taking up more long term binding commitments like wage employment or entrepreneurship.

Migrants intending to resettle permanently in Albania are less likely to return to wage employment over non-participation at their arrival, though, there is evidence that they eventually reintegrate into the labour market. Every month spent in Albania increases their odds of finding a paid job by about 3 percent (see Table 9). Nevertheless, at time of arrival, permanent returnees are significantly more likely to be self-employed over wage employed: unsuccessful returnees only as own account workers, while target savers also as entrepreneurs (see Table 10). With the passing of time, those initially becoming own account workers seem to switch into wage employment, also supporting the "parking lot" hypothesis.

Returning after having accumulated enough savings gives the highest likelihood of being an entrepreneur over a wage employee. This behaviour is consistent with the hypothesis that in the presence of capital constraints nascent entrepreneurs are likely to use migration as a strategy to accumulate the needed funds to start a business (see Mesnard, 2004).

Comparison between the predicted probability of actual occupational choice and the counterfactual probabilities shows that migration has an important effect on 
occupational choice (see Table 11). Compared to having not migrated, return migrants are significantly more likely not to participate in the labour market $(+5.3$ percentage points) and be entrepreneurs (+3.4 percentage points) and less likely to be wage employees (-4.6 percentage points) and own account workers (-4.0 percentage points). Allowing 12 months for reintegration into the labour market, the negative effect on labour market participation completely vanishes and the positive effect on selfemployment becomes stronger: +3.3 percentage points for own account working and +5.9 percentage points for entrepreneurship.

Had the return migrants stayed, they would have been less likely to be entrepreneurs (-.09 percentage points) and more likely to be own account workers $(+1.3$ percentage points) compared to non-migrants. This means that had they stayed, even if they had taken the risk to become self-employed, they would have certainly lacked the capital for expanding the business and for hiring employees. As for non-migrants, the migration experience would have increased their probability to be entrepreneurs by about +2.1 percentage points

\section{Conclusions}

We have analysed the occupational choice of return migrants and non-migrants in the Albanian context. Our data confirm empirical evidence from other developing countries that an important part of the labour force is employed as own account workers. Moreover, own account workers earn on average significantly less compared to both wage employees and entrepreneurs, pointing to the fact that own account workers are rather a marginalised group.

In our empirical approach, we investigated the occupational choice of returnees and non-migrants for non-participation, wage employment, own account work and entrepreneurship, taking into consideration the eventual sample selection bias into return migration. Our results show that own account workers have characteristics closer to those non-participating in the labour market (i.e. lower education levels, failure of the migration target), while entrepreneurship is positively related to schooling, foreign language skills (i.e. Italian), better infrastructure, and target saving migration. Furthermore, with the time spent in Albania after return, permanent returnees opting for non-participation and own account work seem to re-integrate into the labour market and find a way into paid employment, supporting the “parking lot” hypothesis. 
The results of the counterfactual analysis show that if the return migrants had not migrated, they would have been more likely to be own account workers and less likely to be entrepreneurs. Past migration experience, however, has a positive effect on both own account work and entrepreneurship, with the latter effect being significantly stronger. This finding has important policy implications. Even after sorting out small self-employment activities, migration is shown to have an important impact on entrepreneurship. This could include the expansion of a small own account business to a small or medium sized enterprise with paid employees.

Finally, our results show that the impact of return migration on the home economy needs to be differentiated not only by forms of self-employment but also by forms of migration. Target savers are making the strongest direct contribution to employment generation and growth, having the highest odds of being entrepreneurs after return. This suggests that reducing financial constraints domestically could have positive effects for the economy. 


\section{References}

Blanchflower D.G. and A.J. Oswald (1998), "What Makes an Entrepreneur? Evidence on Inheritance and Capital Constraints,” Journal of Labor Economics 16(1): 26-60.

Blau, D.M. (1986), Self-employment, Earnings, and Mobility in Peninsular Malaysia, World Development 14(7): 839-52.

Borjas, G. and B. Bratsberg (1996), "Who leaves? The out-migration of the foreignborn”, Review of Economics Statistics 78(1): 165-76.

Borjas, G. (1989), “Immigrant and emigrant earnings: A longitudinal Study”, Economic Inquiry 27(1): 21-37.

Cuka, E, H. Papapanagos, N. Polo and P. Sanfey (2003), Labor Market Developments in Albania: An Analytical Overview, Review of Development Economics 7(2): 21727.

de Coulon, A. and M. Piracha (2005), "Self-selection and the performance of return migrants: the source country perspective”, Journal of Population Economics 18(4): 779-807.

Dayton-Johnson, J., L.T. Katseli, G. Maniatis, R. Münz, D. Papademetriou (2007), “Gaining from Migration: Towards a New Mobility System”, Paris: OECD Development Centre.

Djajic, S. and R. Milbourne (1988), “A general equilibrium model of guest-worker migration: The source-country perspective”, Journal of International Economics 25(3-4): 335-51.

Dustmann C. (2003), "Return migration, wage differentials and the optimal migration duration”, European Economic Review 47(2): 353-69.

Dustmann C. (1997), "Return migration, uncertainty and precautionary savings”, Journal Development Economics 52(2): 295-316.

Dustmann, C. (1995), “Savings behavior of migrant workers: A life-cycle analysis“, Zeitschrift fü Wirtschafts- und Sozialwissenschaften 115(4), 511-33.

Dustmann, C. and O. Kirchkamp (2002), The optimal migration duration and activity choice after re-migration, Journal of Development Economics 67(2): 351-72.

European Training Foundation (2007), “The contribution of human resources development to migration policy in Albania”, ETF Report, Torino.

Gourieroux, C., A. Monfort, E. Renault and A. Trognon (1987), “Generalised Residuals”, Journal of Econometrics 34(1/2): 5-32.

Green, W.H. (2002), “Econometric Analysis”, 5th edition, New Jersey: Prentice-Hall. 
Harris, J.R. and M.P. Todaro (1970), Migration, Unemployment and Development: A Two-Sector Analysis, American Economic Review 60(1): 126-42.

Hill, J.K. (1987), "Immigrant decisions concerning duration of stay and migratory frequency”, Journal of Development Economics 25(1): 221-34.

Ilahi, N. (1999), "Return Migration and Occupational Change”, Review of Development Economics 3(2): 170-86.

Jasso G. and M.R. Rosenzweig (1988), "How well do US immigrants do? Vintage effects, emigration selectivity, and occupational mobility of immigrants”, in: Schultz P.T. (ed.), Research of Population Economics 6, JAI Press, Greenwich Connecticut London, pp. 229-53.

McCormick, B. and J. Wahba (2001), “Overseas Work Experience, Savings and Entrepreneurship amongst Return Migrants to LDCs”, Scottish Journal of Political Economy 48(2):164-78.

McFadden, D. (1973), “Conditional Logit Analysis of Qualitative Choice Behavior”, in P. Zarembka (ed.), Frontiers in Econometrics, New York: Academic Press,

de Mel, S., D. McKenzie and C. Woodruff (2008), "Who are the Microenterprise Owners? Evidence from Sri Lanka on Tokman vs. de Soto”, IZA Discussion Paper No. 3511, Institute for the Study of Labour, Bonn.

Mesnard, A. (2004), “Temporary migration and capital market imperfections”, Oxford Economic Papers 56(2): 242-62.

Radu, D.C. and G. Epstein (2007), Returns to return migration and determinants of subsequent moves, EALE Conference Paper, EALE Annual Conference 20-22 September 2007, Oslo.

Raffelhüschen, B. (1992), "Labor migration in Europe: Experiences from Germany after unification”, European Economic Review 36(7): 1453-71.

Stark, O. (1991), “The Migration of Labour”, Basil Blackwell, Oxford.

Voicu, A. (2002), Agriculture: Transition Buffer or Black Hole? A Three-State Model of Employment Dynamics, IZA Discussion Paper No. 676, Institute for the Study of Labour, Bonn.

Vullnetari, J. (2007), “Albanian Migration and Development: State of the Art Review”, IMISCOE Working Paper No. 18, Amsterdam: Institute for Migration and Ethnic Studies (IMES). 
The World Bank (2005), “Global Economic Prospects 2006: Economic Implications of

Remittances and Migration", Washington, D.C.: International Bank for Reconstruction and Development/The World Bank.

Zissimopoulos, J.M. and L.A. Karoly (2007), “Transitions to self-employment at older ages: The role of wealth, health, health insurance and other factors”, Labour Economics 14(2): 269-95. 
Table 1: Descriptive statistics by past migration experience; males

\begin{tabular}{|c|c|c|c|c|}
\hline & $\begin{array}{c}\text { Non } \\
\text { Migrants }\end{array}$ & $\begin{array}{l}\text { Return } \\
\text { Migrants }\end{array}$ & \multirow[b]{2}{*}{ difference } & \multirow[b]{2}{*}{ t-test } \\
\hline & $\begin{array}{l}\text { Mean } \\
\text { value }\end{array}$ & $\begin{array}{l}\text { Mean } \\
\text { value }\end{array}$ & & \\
\hline \multicolumn{5}{|l|}{ Individual Characteristics } \\
\hline Age & 41.98 & 36.94 & $5.04^{\star \star \star}$ & 0.000 \\
\hline Education level: primary or less & 0.38 & 0.45 & $-0.065^{\star \star \star}$ & 0.001 \\
\hline Education level: secondary/vocational & 0.47 & 0.48 & -0.005 & 0.810 \\
\hline Education level: tertiary & 0.15 & 0.08 & 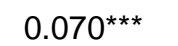 & 0.000 \\
\hline Speaks English & 0.10 & 0.09 & 0.006 & 0.582 \\
\hline Speaks Italian & 0.14 & 0.20 & $-0.062^{\star \star \star}$ & 0.000 \\
\hline Speaks Greek & 0.04 & 0.44 & $-0.408^{\star \star \star}$ & 0.000 \\
\hline Occupation: not working & 0.15 & 0.21 & $-0.058^{\star \star \star}$ & 0.000 \\
\hline Occupation: wage employee & 0.57 & 0.51 & $0.055^{\star \star \star}$ & 0.005 \\
\hline Occupation: own account worker & 0.22 & 0.20 & $0.028 *$ & 0.085 \\
\hline Occupation: entrepreneur & 0.05 & 0.08 & $-0.025^{\star \star \star}$ & 0.009 \\
\hline Monthly income (if working; LEK) & 228,730 & 247,355 & $-18,625$ & 0.264 \\
\hline \multicolumn{5}{|l|}{ Household Characteristics } \\
\hline HH subjective economic status in 1990 & 3.80 & 3.55 & $0.25^{\star \star \star}$ & 0.001 \\
\hline HH subjective economic status in 2005 & 3.98 & 4.01 & -0.027 & 0.693 \\
\hline Married & 0.81 & 0.81 & 0.000 & 0.991 \\
\hline Household size & 4.94 & 5.07 & $-0.123^{*}$ & 0.073 \\
\hline Number of other $\mathrm{HH}$ members a migrant & 0.49 & 0.79 & $-0.304^{\star \star \star}$ & 0.000 \\
\hline \multicolumn{5}{|l|}{ Social Capital } \\
\hline No. of friends & 2.04 & 2.05 & -0.012 & 0.871 \\
\hline \multicolumn{5}{|l|}{ Community and Regional Characteristics } \\
\hline Community has piped water & 0.80 & 0.71 & $0.095^{\star \star \star}$ & 0.000 \\
\hline Community has banking service & 0.62 & 0.50 & $0.115^{\star \star \star}$ & 0.000 \\
\hline Urban area & 0.69 & 0.57 & $0.121^{* * *}$ & 0.000 \\
\hline Region: Tirana & 0.29 & 0.20 & $0.091^{\star * \star}$ & 0.000 \\
\hline Region: Coastal & 0.22 & 0.29 & $-0.076^{\star \star \star}$ & 0.000 \\
\hline Region: Central & 0.22 & 0.26 & $-0.038^{\star \star}$ & 0.022 \\
\hline Region: Mountain & 0.27 & 0.24 & 0.023 & 0.177 \\
\hline \multicolumn{5}{|l|}{ Migration history } \\
\hline Time since returned (months) & & 55.70 & & \\
\hline Re-migration intention: No & & 0.50 & & \\
\hline Re-migration intention: Yes & & 0.36 & & \\
\hline Re-migration intention: Don't know & & 0.14 & & \\
\hline Return reason: family & & 0.25 & & \\
\hline Return reason: unsuccessful & & 0.35 & & \\
\hline Return reason: temporary/seasonal permit & & 0.21 & & \\
\hline Return reason: accumulated enough savings & & 0.19 & & \\
\hline Observations & 2,049 & 962 & & \\
\hline ** significant at $5 \% ;{ }^{\star \star \star}$ significant at $1 \%$ & & & & \\
\hline
\end{tabular}


Table 2: Descriptive statistics by occupational choice: male non-migrants (mean values)

\begin{tabular}{|c|c|c|c|c|}
\hline & Not working & $\begin{array}{c}\text { Wage } \\
\text { employee }\end{array}$ & $\begin{array}{l}\text { Own account } \\
\text { worker }\end{array}$ & Entrepreneur \\
\hline \multicolumn{5}{|l|}{ Individual Characteristics } \\
\hline Age & 35.63 & 42.57 & 43.90 & 45.91 \\
\hline Education level: primary or less & 0.51 & 0.30 & 0.52 & 0.24 \\
\hline Education level: secondary/vocational & 0.45 & 0.49 & 0.42 & 0.56 \\
\hline Education level: tertiary & 0.04 & 0.21 & 0.05 & 0.20 \\
\hline Speaks English & 0.07 & 0.13 & 0.04 & 0.12 \\
\hline Speaks Italian & 0.15 & 0.16 & 0.05 & 0.22 \\
\hline Speaks Greek & 0.04 & 0.04 & 0.03 & 0.04 \\
\hline Monthly income (if working; old LEK) & n.a. & 259,138 & 207,111 & 645,081 \\
\hline \multicolumn{5}{|l|}{ Household Characteristics } \\
\hline HH subjective economic status in 1990 & 3.71 & 3.85 & 3.68 & 4.01 \\
\hline HH subjective economic status in 2005 & 3.14 & 4.10 & 3.89 & 5.42 \\
\hline Married & 0.52 & 0.86 & 0.87 & 0.92 \\
\hline Household size & 5.09 & 4.85 & 5.14 & 4.72 \\
\hline \multicolumn{5}{|l|}{ Social Capital } \\
\hline No. of friends & 1.95 & 1.99 & 2.20 & 2.11 \\
\hline \multicolumn{5}{|c|}{ Community and Regional Characteristics } \\
\hline Community has piped water & 0.84 & 0.82 & 0.72 & 0.90 \\
\hline Community has banking service & 0.69 & 0.68 & 0.42 & 0.76 \\
\hline Urban area & 0.78 & 0.75 & 0.46 & 0.78 \\
\hline Region: Tirana & 0.25 & 0.35 & 0.17 & 0.34 \\
\hline Region: Coastal & 0.15 & 0.21 & 0.28 & 0.25 \\
\hline Region: Central & 0.26 & 0.22 & 0.21 & 0.22 \\
\hline Region: Mountain & 0.33 & 0.23 & 0.34 & 0.19 \\
\hline Observations & 314 & 1,167 & 457 & 111 \\
\hline
\end{tabular}


Table 3: Descriptive statistics by occupational choice: male return migrants (mean values)

\begin{tabular}{|c|c|c|c|c|}
\hline & Not working & $\begin{array}{l}\text { Wage } \\
\text { employee }\end{array}$ & $\begin{array}{l}\text { Own account } \\
\text { worker }\end{array}$ & Entrepreneur \\
\hline \multicolumn{5}{|l|}{ Individual Characteristics } \\
\hline Age & 32.72 & 37.11 & 39.65 & 40.43 \\
\hline Education level: primary or less & 0.52 & 0.45 & 0.49 & 0.16 \\
\hline Education level: secondary/vocational & 0.44 & 0.44 & 0.49 & 0.77 \\
\hline Education level: tertiary & 0.04 & 0.11 & 0.03 & 0.08 \\
\hline Speaks English & 0.12 & 0.10 & 0.04 & 0.14 \\
\hline Speaks Italian & 0.22 & 0.20 & 0.10 & 0.34 \\
\hline Speaks Greek & 0.56 & 0.42 & 0.35 & 0.51 \\
\hline Monthly income (if working; LEK) & n.a. & 327,028 & 223,262 & 445,792 \\
\hline \multicolumn{5}{|l|}{ Household Characteristics } \\
\hline HH subjective economic status in 1990 & 3.45 & 3.45 & 3.64 & 4.29 \\
\hline HH subjective economic status in 2005 & 3.31 & 4.02 & 4.24 & 5.18 \\
\hline Married & 0.61 & 0.83 & 0.93 & 0.92 \\
\hline Household size & 5.45 & 4.93 & 5.09 & 4.91 \\
\hline \multicolumn{5}{|l|}{ Social Capital } \\
\hline No. of friends & 2.09 & 1.89 & 2.18 & 2.64 \\
\hline \multicolumn{5}{|l|}{ Community and Regional Characteristics } \\
\hline Community has piped water & 0.70 & 0.69 & 0.67 & 0.94 \\
\hline Community has banking service & 0.53 & 0.51 & 0.37 & 0.78 \\
\hline Urban area & 0.54 & 0.60 & 0.43 & 0.75 \\
\hline Region: Tirana & 0.10 & 0.27 & 0.16 & 0.18 \\
\hline Region: Coastal & 0.15 & 0.29 & 0.39 & 0.43 \\
\hline Region: Central & 0.25 & 0.27 & 0.25 & 0.25 \\
\hline Region: Mountain & 0.50 & 0.17 & 0.21 & 0.14 \\
\hline \multicolumn{5}{|l|}{ Migration history } \\
\hline Time since returned (months) & 25.00 & 54.49 & 74.74 & 85.68 \\
\hline Re-migration intention: No & 0.24 & 0.50 & 0.65 & 0.84 \\
\hline Re-migration intention: Yes & 0.62 & 0.36 & 0.21 & 0.08 \\
\hline Re-migration intention: Don't know & 0.15 & 0.14 & 0.14 & 0.08 \\
\hline Return reason: family & 0.27 & 0.27 & 0.19 & 0.21 \\
\hline Return reason: unsuccessful & 0.34 & 0.33 & 0.45 & 0.29 \\
\hline Return reason: temporary/seasonal permit & 0.27 & 0.22 & 0.17 & 0.10 \\
\hline Return reason: accumulated enough savings & 0.12 & 0.18 & 0.19 & 0.40 \\
\hline Observations & 203 & 495 & 187 & 77 \\
\hline
\end{tabular}

Notes: The sample included is the potential labour force (i.e. not enrolled in education, not retired, not handicapped, and not in military service) aged 20 to 64 . $\mathrm{HH}$ subjective economic status: $1=$ poor to $10=$ =rich. 
Table 4: Sample selection test

\begin{tabular}{|c|c|c|c|c|}
\hline & Probit & \multicolumn{3}{|c|}{ Multinomial Logit } \\
\hline & $\begin{array}{l}\text { Return migration } \\
\text { vs. non migration }\end{array}$ & \begin{tabular}{|c} 
Not working vs. \\
Wage employment
\end{tabular} & $\begin{array}{c}\text { Own acc. work vs. } \\
\text { Wage } \\
\text { employment }\end{array}$ & $\begin{array}{c}\text { Entrepreneur vs. } \\
\text { Wage } \\
\text { employment } \\
\end{array}$ \\
\hline \multicolumn{5}{|l|}{ Individual Characteristics } \\
\hline Age & $\begin{array}{c}-0.03957 \\
{[0.00354]^{\star \star \star}}\end{array}$ & $\begin{array}{c}0.00655 \\
{[0.00984]}\end{array}$ & $\begin{array}{c}0.01253 \\
{[0.00877]}\end{array}$ & $\begin{array}{c}0.0401 \\
{[0.01355]^{\star \star \star}}\end{array}$ \\
\hline Education level: secondary & $\begin{array}{l}-0.09207 \\
{[0.06091]}\end{array}$ & $\begin{array}{c}-0.44175 \\
{[0.12397]^{\star \star \star}}\end{array}$ & $\begin{array}{c}-0.35479 \\
{[0.10857]^{\star \star \star}}\end{array}$ & $\begin{array}{c}0.57971 \\
{[0.20570]^{\star \star \star}}\end{array}$ \\
\hline Education level: tertiary & $\begin{array}{c}-0.42737 \\
{[0.11387]^{\star \star *}}\end{array}$ & $\begin{array}{c}-1.89139 \\
{[0.30090]^{\star \star \star}}\end{array}$ & $\begin{array}{c}-1.60404 \\
{[0.24919]^{\star \star \star}}\end{array}$ & $\begin{array}{l}-0.13728 \\
{[0.33474]}\end{array}$ \\
\hline Speaks English & $\begin{array}{l}-0.14385 \\
{[0.11600]}\end{array}$ & $\begin{array}{c}0.15076 \\
{[0.23439]}\end{array}$ & $\begin{array}{c}-0.006 \\
{[0.26001]}\end{array}$ & $\begin{array}{c}0.04896 \\
{[0.29730]}\end{array}$ \\
\hline Speaks Italian & $\begin{array}{c}0.31745 \\
{[0.08606]^{\star \star \star}}\end{array}$ & $\begin{array}{l}-0.02154 \\
{[0.19230]}\end{array}$ & $\begin{array}{c}-0.38675 \\
{[0.21187]^{*}}\end{array}$ & $\begin{array}{c}0.59069 \\
{[0.24663]^{\star *}}\end{array}$ \\
\hline Speaks Greek & $\begin{array}{c}1.69942 \\
{[0.07897]^{\star * \star}}\end{array}$ & $\begin{array}{l}-0.43435 \\
{[0.49019]}\end{array}$ & $\begin{array}{l}-0.01558 \\
{[0.46360]}\end{array}$ & $\begin{array}{l}-0.38249 \\
{[0.68684]}\end{array}$ \\
\hline \multicolumn{5}{|l|}{ Household Characteristics } \\
\hline HH subjective economic status in 1990 & $\begin{array}{l}-0.00444 \\
{[0.01587]}\end{array}$ & $\begin{array}{c}0.03957 \\
{[0.03232]}\end{array}$ & $\begin{array}{c}0.09499 \\
{[0.02868]^{\star \star \star}}\end{array}$ & $\begin{array}{c}0.07425 \\
{[0.04239]^{*}}\end{array}$ \\
\hline Married & $\begin{array}{c}0.91228 \\
{[0.09470]^{\star \star \star}}\end{array}$ & $\begin{array}{c}-1.71602 \\
{[0.22895]^{\star \star \star}}\end{array}$ & $\begin{array}{c}0.01867 \\
{[0.22977]}\end{array}$ & $\begin{array}{c}0.147 \\
{[0.39018]}\end{array}$ \\
\hline Household size & $\begin{array}{c}-0.05819 \\
{[0.01711]^{\star \star \star}}\end{array}$ & $\begin{array}{c}0.09115 \\
{[0.03343]^{\star \star \star}}\end{array}$ & $\begin{array}{c}0.00431 \\
{[0.03124]}\end{array}$ & $\begin{array}{c}0.07087 \\
{[0.05234]}\end{array}$ \\
\hline \multicolumn{5}{|l|}{ Social Capital } \\
\hline No. of friends & $\begin{array}{c}0.01583 \\
{[0.01403]}\end{array}$ & $\begin{array}{l}-0.00094 \\
{[0.03350]}\end{array}$ & $\begin{array}{c}0.08199 \\
{[0.02604]^{\star \star \star}}\end{array}$ & $\begin{array}{c}0.07491 \\
{[0.03439]^{\star \star}}\end{array}$ \\
\hline Community has piped water & $\begin{array}{c}-0.22409 \\
{[0.08431]^{\star \star *}}\end{array}$ & $\begin{array}{c}0.28191 \\
{[0.19302]}\end{array}$ & $\begin{array}{c}0.30639 \\
{[0.14643]^{\star \star}}\end{array}$ & $\begin{array}{c}0.88442 \\
{[0.33863]^{\star \star \star}}\end{array}$ \\
\hline Community has banking service & $\begin{array}{c}0.09585 \\
{[0.10648]}\end{array}$ & $\begin{array}{c}0.09756 \\
{[0.22764]}\end{array}$ & $\begin{array}{l}-0.20843 \\
{[0.19098]}\end{array}$ & $\begin{array}{c}0.74304 \\
{[0.37074]^{\star \star}}\end{array}$ \\
\hline Urban area & $\begin{array}{c}0.22032 \\
{[0.08561]^{\star \star}}\end{array}$ & $\begin{array}{c}0.28733 \\
{[0.19620]}\end{array}$ & $\begin{array}{c}0.40157 \\
{[0.16780]^{\star *}}\end{array}$ & $\begin{array}{c}0.40531 \\
{[0.23776]^{*}}\end{array}$ \\
\hline Region: Coastal & $\begin{array}{c}0.18507 \\
{[0.08488]^{\star \star}}\end{array}$ & $\begin{array}{c}0.78824 \\
{[0.17522]^{\star \star \star}}\end{array}$ & $\begin{array}{c}0.03383 \\
{[0.16882]}\end{array}$ & $\begin{array}{c}0.14273 \\
{[0.24155]}\end{array}$ \\
\hline Region: Central & $\begin{array}{l}-0.03849 \\
{[0.08809]}\end{array}$ & $\begin{array}{c}1.41845 \\
{[0.17125]^{\star \star \star}}\end{array}$ & $\begin{array}{c}0.37372 \\
{[0.16489]^{\star \star}}\end{array}$ & $\begin{array}{c}0.23145 \\
{[0.26063]}\end{array}$ \\
\hline Region: Mountain & $\begin{array}{c}-0.23368 \\
{[0.10492]^{\star \star}}\end{array}$ & $\begin{array}{c}0.61156 \\
{[0.23501]^{\star \star \star}}\end{array}$ & $\begin{array}{c}-0.77956 \\
{[0.19678]^{\star \star \star}}\end{array}$ & $\begin{array}{l}-0.57952 \\
{[0.37322]}\end{array}$ \\
\hline \multicolumn{5}{|l|}{ Selection Controls } \\
\hline $\mathrm{Nr}$. of other $\mathrm{HH}$ members a migrant & $\begin{array}{c}0.21027 \\
{[0.03016]^{\star \star *}}\end{array}$ & & & \\
\hline Return Migrant & & $\begin{array}{c}1.5655 \\
{[0.81205]^{*}}\end{array}$ & $\begin{array}{l}-0.40754 \\
{[0.76479]}\end{array}$ & $\begin{array}{c}1.58417 \\
{[1.13330]}\end{array}$ \\
\hline Generalized Residual (selection eq.) & & $\begin{array}{c}-0.77397 \\
{[0.46934]^{*}}\end{array}$ & $\begin{array}{c}0.21892 \\
{[0.44249]}\end{array}$ & $\begin{array}{l}-0.63279 \\
{[0.65087]}\end{array}$ \\
\hline Constant & $\begin{array}{c}0.43492 \\
{[0.18720]^{\star *}}\end{array}$ & $\begin{array}{c}-2.24826 \\
{[0.57315]^{\star \star \star}}\end{array}$ & $\begin{array}{c}-1.41536 \\
{[0.53243]^{\star \star \star}}\end{array}$ & $\begin{array}{c}-6.74312 \\
{[0.86782]^{\star \star \star}}\end{array}$ \\
\hline Observations & 3011 & & 3011 & \\
\hline LR chi-sq & 1017.48 & & 794.05 & \\
\hline Pseudo R-sq & 0.27 & & 0.12 & \\
\hline $\begin{array}{l}\text { Standard errors in brackets } \\
* \text { significant at } 10 \% ;{ }^{* *} \text { significant at } 5\end{array}$ & ignificant at $1 \%$ & & & \\
\hline
\end{tabular}


Table 5: Estimation results of occupational choice; separately for Non Migrants and Return Migrants

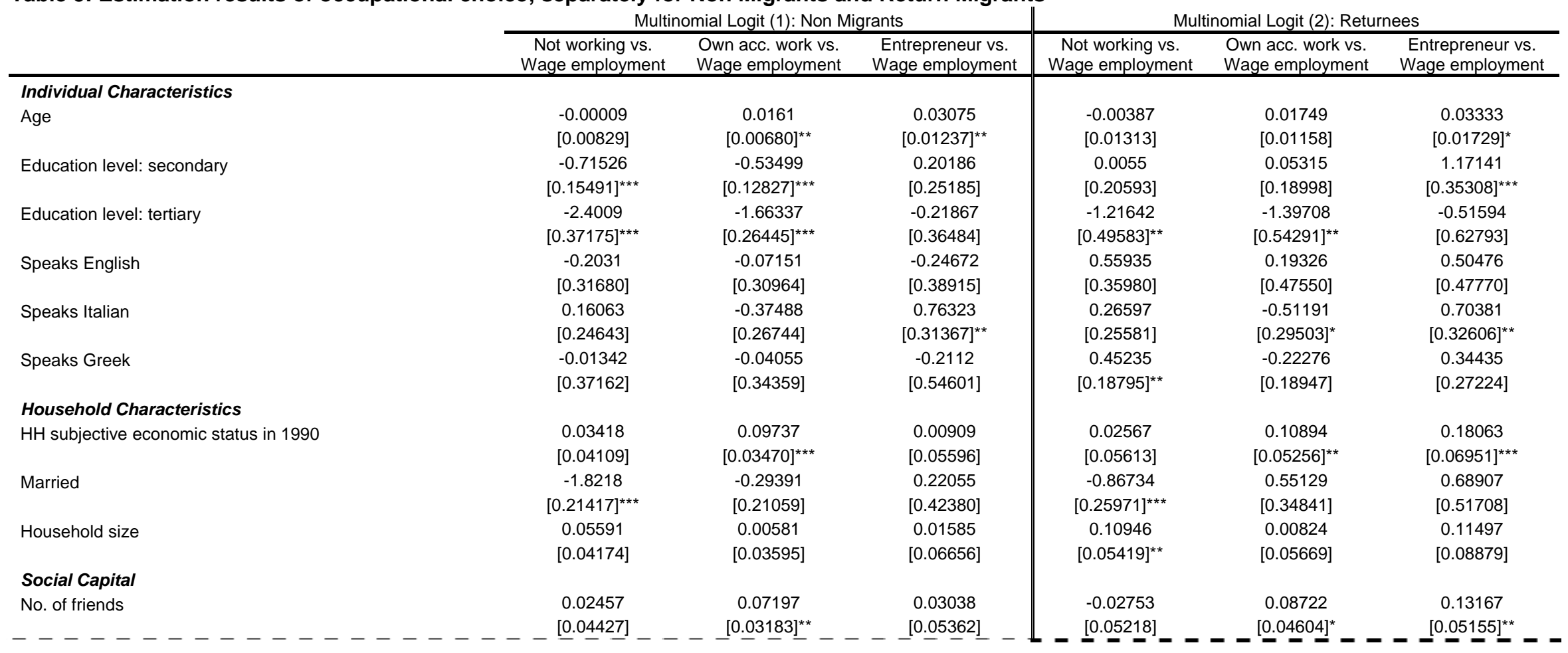


Table 5: Estimation results of occupational choice; separately for Non Migrants and Return Migrants (continued)

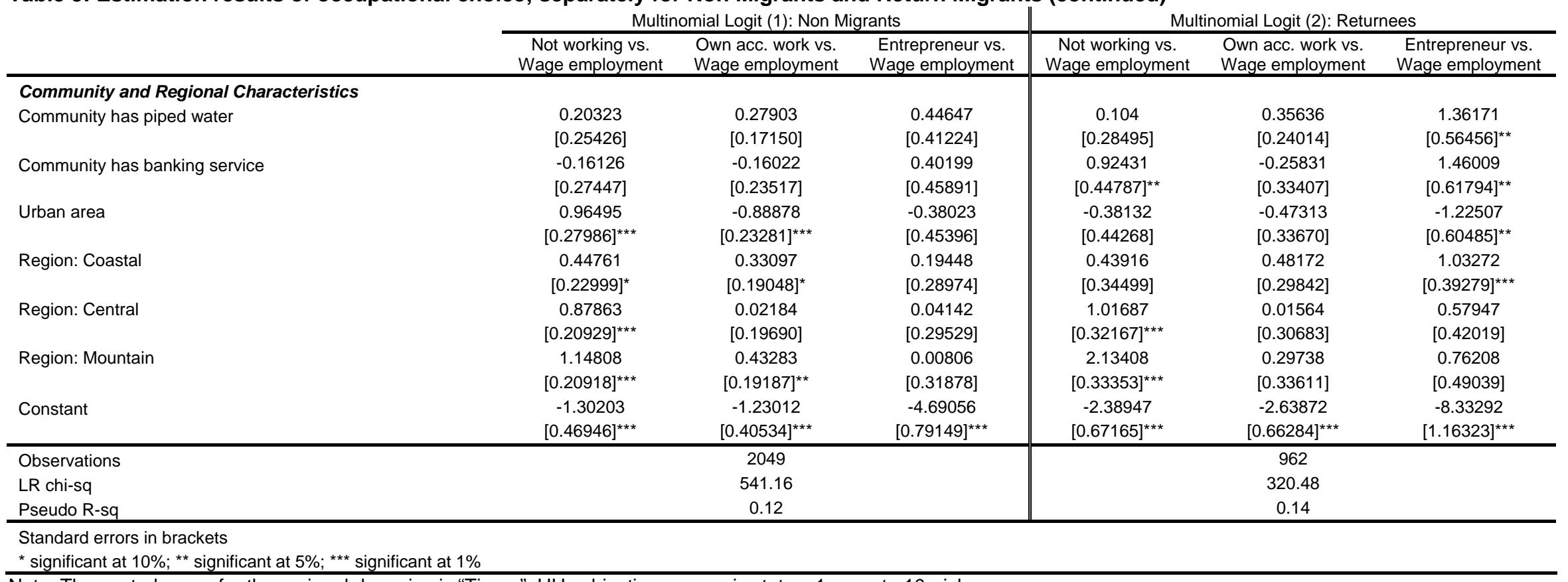

Note: The control group for the regional dummies is "Tirana". HH subjective economic status: 1=poor to 10=rich. 
Table 6: Estimation results of occupational choice; jointly for Non Migrants (NM) and Return Migrants (RM)

\begin{tabular}{|c|c|c|c|c|c|c|c|}
\hline & \multicolumn{7}{|c|}{ Multinomial Logit (3) } \\
\hline & $\begin{array}{l}\text { Not working NM } \\
\text { vs. Wage } \\
\text { employed NM } \\
\end{array}$ & $\begin{array}{l}\text { Own acc. worker } \\
\text { NM vs. Wage } \\
\text { employed NM } \\
\end{array}$ & $\begin{array}{l}\text { Entrepreneur } \\
\text { NM vs. Wage } \\
\text { employed NM } \\
\end{array}$ & $\begin{array}{l}\text { Not working RM } \\
\text { vs. Wage } \\
\text { employed NM } \\
\end{array}$ & $\begin{array}{l}\text { Wage employed } \\
\text { RM vs. Wage } \\
\text { employed RM } \\
\end{array}$ & $\begin{array}{l}\text { Own acc. worker } \\
\text { RM vs. Wage } \\
\text { employed NM } \\
\end{array}$ & $\begin{array}{l}\text { Entrepreneur } \\
\text { RM vs. Wage } \\
\text { employed NM } \\
\end{array}$ \\
\hline \multicolumn{8}{|l|}{ Individual Characteristics } \\
\hline \multirow{2}{*}{ Age } & -0.00402 & 0.01687 & 0.03151 & -0.05773 & -0.05724 & -0.04494 & -0.02747 \\
\hline & {$[0.00830]$} & {$[0.00678]^{\star \star}$} & {$[0.01238]^{\star \star}$} & {$[0.01184]^{\star \star \star}$} & {$[0.00754]^{\star \star *}$} & {$[0.01022]^{\star \star \star}$} & {$[0.01590]^{*}$} \\
\hline \multirow[t]{2}{*}{ Education level: secondary } & -0.6516 & -0.51824 & 0.22008 & -0.58879 & -0.47852 & -0.44163 & 0.61566 \\
\hline & {$[0.15067]^{\star \star *}$} & {$[0.12664]^{\star \star \star}$} & {$[0.25057]$} & {$[0.19581]^{\star \star \star}$} & {$[0.13642]^{\star \star \star}$} & {$[0.17996]^{\star \star}$} & {$[0.34539]^{*}$} \\
\hline \multirow[t]{2}{*}{ Education level: tertiary } & -2.2466 & -1.61999 & -0.1949 & -2.37156 & -0.79142 & -2.22032 & -1.33771 \\
\hline & {$[0.36399]^{\star \star \star}$} & {$[0.26192]^{\star \star \star}$} & {$[0.36075]$} & {$[0.47369]^{\star \star \star}$} & {$[0.24191]^{\star \star \star}$} & {$[0.52439]^{\star \star \star}$} & {$[0.59832]^{\star \star}$} \\
\hline \multirow[t]{2}{*}{ Speaks English } & -0.32428 & -0.03042 & -0.22934 & 0.21185 & -0.56444 & -0.45807 & -0.11378 \\
\hline & [0.29989] & {$[0.30317]$} & {$[0.38737]$} & [0.33955] & {$[0.25738]^{\star \star}$} & {$[0.47214]$} & [0.45542] \\
\hline \multirow[t]{2}{*}{ Speaks Italian } & 0.11015 & -0.48943 & 0.72241 & 0.84736 & 0.63137 & 0.19831 & 1.30066 \\
\hline & {$[0.22851]$} & {$[0.25635]^{\star}$} & {$[0.30054]^{\star *}$} & {$[0.26118]^{\star \star \star}$} & {$[0.18780]^{\star \star \star}$} & [0.29830] & {$[0.32541]^{\star \star *}$} \\
\hline \multirow[t]{2}{*}{ Speaks Greek } & -0.1852 & -0.19352 & -0.02856 & 3.28304 & 2.79884 & 2.55841 & 3.07783 \\
\hline & [0.34353] & [0.32629] & [0.53633] & {$[0.22327]^{\star \star \star}$} & {$[0.18471]^{\star \star *}$} & {$[0.22923]^{\star \star \star}$} & {$[0.29271]^{\star \star *}$} \\
\hline \multicolumn{8}{|l|}{ Household Characteristics } \\
\hline \multirow[t]{2}{*}{ HH subjective economic status in 1990} & 0.03133 & 0.0828 & 0.0078 & 0.0027 & -0.03375 & 0.09807 & 0.14012 \\
\hline & [0.04011] & {$[0.03390]^{\star \star}$} & {$[0.05549]$} & {$[0.05210]$} & {$[0.03613]$} & {$[0.04923]^{\star *}$} & {$[0.06566]^{\star \star}$} \\
\hline \multirow[t]{2}{*}{ Married } & -1.75576 & -0.31102 & 0.23488 & 0.03029 & 0.99726 & 1.61845 & 1.61906 \\
\hline & {$[0.20906]^{\star * *}$} & {$[0.20658]$} & [0.41988] & {$[0.25864]$} & {$[0.20470]^{\star \star \star}$} & {$[0.34294]^{\star \star *}$} & {$[0.51093]^{\star \star \star}$} \\
\hline \multirow[t]{2}{*}{ Household size } & 0.06276 & 0.00189 & 0.01504 & 0.01244 & -0.08932 & -0.07402 & 0.02198 \\
\hline & {$[0.04077]$} & [0.03585] & [0.06713] & {$[0.05160]$} & {$[0.03844]^{\star \star}$} & {$[0.05220]$} & [0.07895] \\
\hline \multicolumn{8}{|l|}{ Social Capital } \\
\hline No. of friends & 0.0189 & 0.07566 & 0.03199 & -0.02081 & 0.00418 & 0.10016 & 0.14743 \\
\hline---- & [0.04030] & {$[0.02925]^{\star \star *}$} & [0.05152] & {$[0.05336]$} & {$[0.03776]$} & {$[0.04182]^{\star \star}$} & {$[0.04398]^{\star * *}$} \\
\hline
\end{tabular}


Table 6: Estimation results of occupational choice; jointly for Non Migrants (NM) and Return Migrants (RM) (continued)

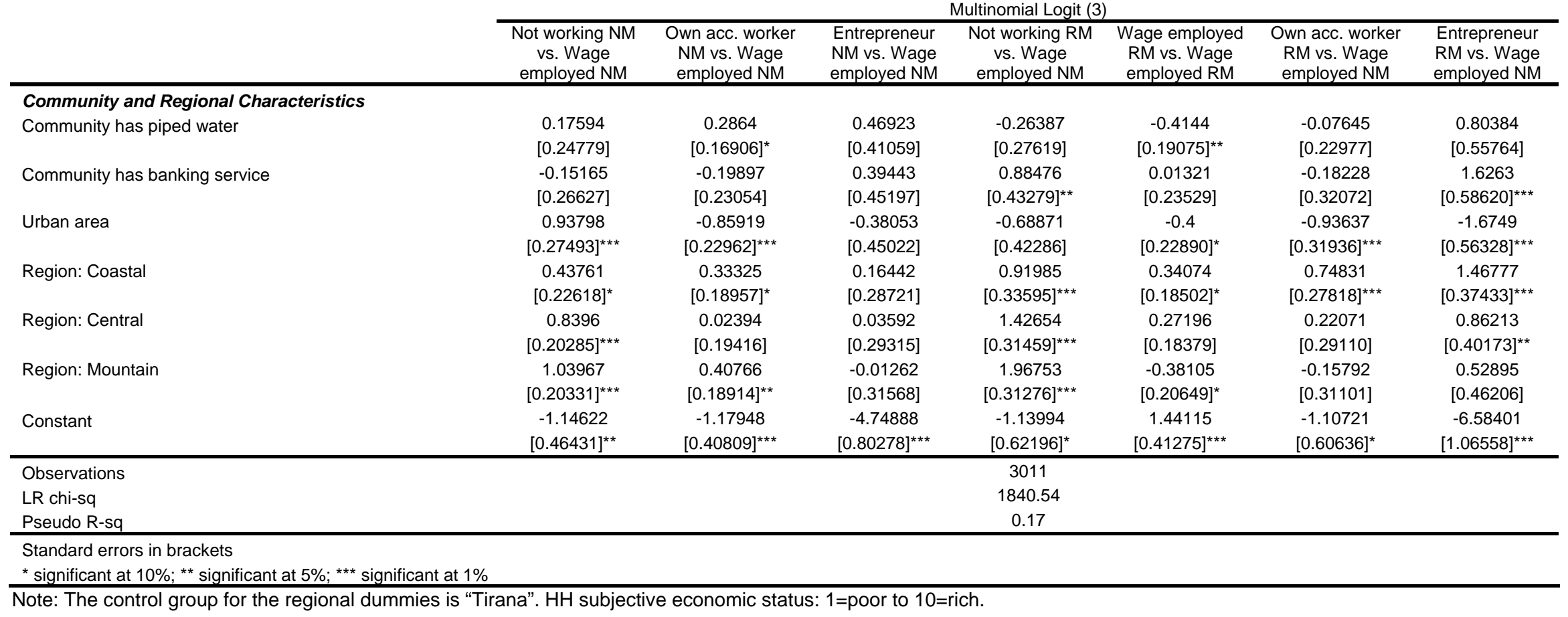


Table 7: Odds ratios for occupational choice

\begin{tabular}{|c|c|c|c|c|c|c|c|c|}
\hline & Age & $\begin{array}{l}\text { Education } \\
\text { level: } \\
\text { secondary }\end{array}$ & $\begin{array}{c}\text { Education } \\
\text { level: } \\
\text { tertiary }\end{array}$ & $\begin{array}{l}\text { Speaks } \\
\text { English }\end{array}$ & $\begin{array}{l}\text { Speaks } \\
\text { Italian }\end{array}$ & $\begin{array}{l}\text { Speaks } \\
\text { Greek }\end{array}$ & $\begin{array}{c}\text { Subjective } \\
\text { econ. } \\
\text { status } 1990\end{array}$ & Married \\
\hline \multicolumn{9}{|c|}{ Non Migrants } \\
\hline SW vs. SN & 1.00 & $1.92^{\star \star *}$ & $9.46^{\star * *}$ & 1.38 & 0.90 & 1.20 & 0.97 & $5.79 * \star *$ \\
\hline SO vs. SN & $1.02^{\star \star}$ & 1.14 & 1.87 & 1.34 & $0.55^{\star}$ & 0.99 & 1.05 & $4.24^{\star \star \star}$ \\
\hline SO vs. SW & $1.02^{\star \star}$ & $0.60 * * \star$ & $0.20 * * \star$ & 0.97 & $0.61^{*}$ & 0.82 & $1.09 * \star$ & 0.73 \\
\hline SE vs. SN & $1.04^{\star \star}$ & $2.39 * \star \star$ & $7.78^{\star \star \star}$ & 1.10 & $1.84^{*}$ & 1.17 & 0.98 & $7.32^{\star \star \star}$ \\
\hline SE vs. SW & $1.03^{\star \star}$ & 1.25 & 0.82 & 0.80 & $2.06^{\star \star}$ & 0.97 & 1.01 & 1.26 \\
\hline SE vs. SO & 1.01 & $2.09 * * \star$ & $4.16^{\star \star \star}$ & 0.82 & $3.36^{\star \star \star}$ & 1.18 & 0.93 & 1.73 \\
\hline \multicolumn{9}{|c|}{ Return Migrants } \\
\hline RW vs. RN & 1.00 & 1.12 & $4.86^{\star \star \star}$ & $0.46^{\star \star}$ & 0.81 & $0.62^{\star \star \star}$ & 0.96 & $2.63^{\star * *}$ \\
\hline RO vs. RN & 1.01 & 1.16 & 1.16 & 0.51 & $0.52^{*}$ & $0.48^{\star \star \star}$ & 1.10 & $4.89 * \star \star$ \\
\hline RO vs. RW & 1.01 & 1.04 & $0.24^{\star \star \star}$ & 1.11 & 0.65 & 0.79 & $1.14^{\star \star}$ & $1.86^{\star}$ \\
\hline RE vs. RN & 1.03 & $3.33^{\star \star \star}$ & 2.81 & 0.72 & 1.57 & 0.81 & $1.15^{\star}$ & $4.90^{\star \star \star}$ \\
\hline RE vs. RW & $1.03^{*}$ & 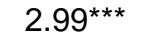 & 0.58 & 1.57 & $1.95^{\star \star}$ & 1.32 & $1.19 * *$ & 1.86 \\
\hline RE vs. RO & 1.02 & $2.88^{\star * \star}$ & 2.42 & 1.41 & $3.01^{* * *}$ & $1.68^{*}$ & 1.04 & 1.00 \\
\hline \multicolumn{9}{|c|}{ Return Migrants vs. Non Migrants } \\
\hline RN vs. SN & $0.95^{\star \star \star}$ & 1.06 & 0.88 & 1.71 & $2.09 * \star$ & $32.08^{\star \star \star}$ & 0.97 & $5.97 * \star *$ \\
\hline RW vs. SW & $0.94^{\star * \star}$ & $0.62^{\star \star \star}$ & $0.45^{\star \star \star}$ & $0.57^{\star *}$ & $1.88^{\star * *}$ & $16.43^{\star \star \star}$ & 0.97 & $2.71 * \star \star$ \\
\hline RO vs. SO & $0.96^{\star * *}$ & $0.64^{\star *}$ & $0.11^{* * *}$ & 0.63 & 1.22 & $12.92^{\star \star \star}$ & $1.10^{\star \star}$ & $5.05^{\star * *}$ \\
\hline RE vs. SE & $0.94^{* * *}$ & 1.49 & $0.32^{*}$ & 1.12 & 1.78 & $22.34^{\star * \star}$ & 1.14 & $3.99 * *$ \\
\hline
\end{tabular}

Table 7: Odds ratios for occupational choice (continued)

\begin{tabular}{|c|c|c|c|c|c|c|c|c|}
\hline & HH size & $\begin{array}{l}\text { No. of } \\
\text { friends }\end{array}$ & $\begin{array}{l}\text { Piped } \\
\text { water }\end{array}$ & $\begin{array}{l}\text { Banking } \\
\text { services }\end{array}$ & $\begin{array}{l}\text { Urban } \\
\text { area }\end{array}$ & $\begin{array}{c}\text { Coastal } \\
\text { region }\end{array}$ & $\begin{array}{c}\text { Central } \\
\text { region }\end{array}$ & $\begin{array}{c}\text { Mountain } \\
\text { region }\end{array}$ \\
\hline \multicolumn{9}{|c|}{ Non Migrants } \\
\hline SW vs. SN & 0.94 & 0.98 & 0.84 & 1.16 & $0.39 * \star \star$ & $0.65^{*}$ & $0.43^{\star * \star}$ & $0.35^{\star \star \star}$ \\
\hline SO vs. SN & 0.94 & 1.06 & 1.12 & 0.95 & $0.17^{\star \star \star}$ & 0.90 & $0.44^{\star \star *}$ & $0.53^{\star \star \star}$ \\
\hline SO vs. SW & 1.00 & $1.08^{* *}$ & $1.33^{\star}$ & 0.82 & $0.42^{\star \star \star}$ & $1.40^{*}$ & 1.02 & $1.50 * \star$ \\
\hline SE vs. SN & 0.95 & 1.01 & 1.34 & 1.73 & $0.27^{\star \star \star}$ & 0.76 & $0.45^{\star \star}$ & $0.35^{\star \star \star}$ \\
\hline SE vs. SW & 1.02 & 1.03 & 1.60 & 1.48 & 0.68 & 1.18 & 1.04 & 0.99 \\
\hline SE vs. SO & 1.01 & 0.96 & 1.20 & 1.81 & 1.61 & 0.84 & 1.01 & 0.66 \\
\hline \multicolumn{9}{|c|}{ Return Migrants } \\
\hline RW vs. RN & $0.90 *$ & 1.03 & 0.86 & $0.42^{\star \star}$ & 1.33 & $0.56^{*}$ & $0.32^{\star \star \star}$ & $0.10^{\star \star *}$ \\
\hline RO vs. RN & 0.92 & $1.13^{\star \star}$ & 1.21 & $0.34^{\star \star}$ & 0.78 & 0.84 & $0.30^{* * *}$ & $0.12^{\star \star \star}$ \\
\hline RO vs. RW & 1.02 & $1.10^{\star \star}$ & 1.40 & 0.82 & 0.58 & 1.50 & 0.95 & 1.25 \\
\hline RE vs. RN & 1.01 & 1.18 & $2.91^{*}$ & 2.10 & 0.37 & 1.73 & 0.57 & $0.24^{\star \star *}$ \\
\hline RE vs. RW & 1.12 & 1.15 & $3.38^{\star *}$ & $5.02^{\star \star \star}$ & $0.28^{\star \star}$ & $3.09 * * *$ & 1.80 & $2.48^{*}$ \\
\hline RE vs. RO & 1.10 & 1.05 & 2.41 & $6.10^{\star \star *}$ & 0.48 & $2.05^{\star}$ & 1.90 & 1.99 \\
\hline \multicolumn{9}{|c|}{ Return Migrants vs. Non Migrants } \\
\hline RN vs. SN & 0.95 & 0.96 & 0.64 & $2.82^{\star \star}$ & 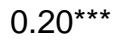 & 1.62 & $1.80^{\star}$ & $2.53^{\star \star \star}$ \\
\hline RW vs. SW & $0.91^{\star *}$ & 1.00 & $0.66^{\star *}$ & 1.01 & $0.67^{*}$ & $1.41^{*}$ & 1.31 & $0.68^{*}$ \\
\hline RO vs. SO & 0.93 & $1.11^{\star \star}$ & 0.93 & 0.83 & $0.39 * * \star$ & $2.11^{\star \star \star}$ & 1.25 & 0.85 \\
\hline RE vs. SE & 1.01 & $1.12^{*}$ & 1.40 & $3.43^{*}$ & $0.27^{*}$ & $3.68^{\star * \star}$ & $2.28^{*}$ & 1.72 \\
\hline
\end{tabular}

Notes: Odds ratios computed based on the estimation in Table 6 . The control group for the regional dummies is "Tirana". 
Table 8: Estimation results of occupational choice models; return migrants

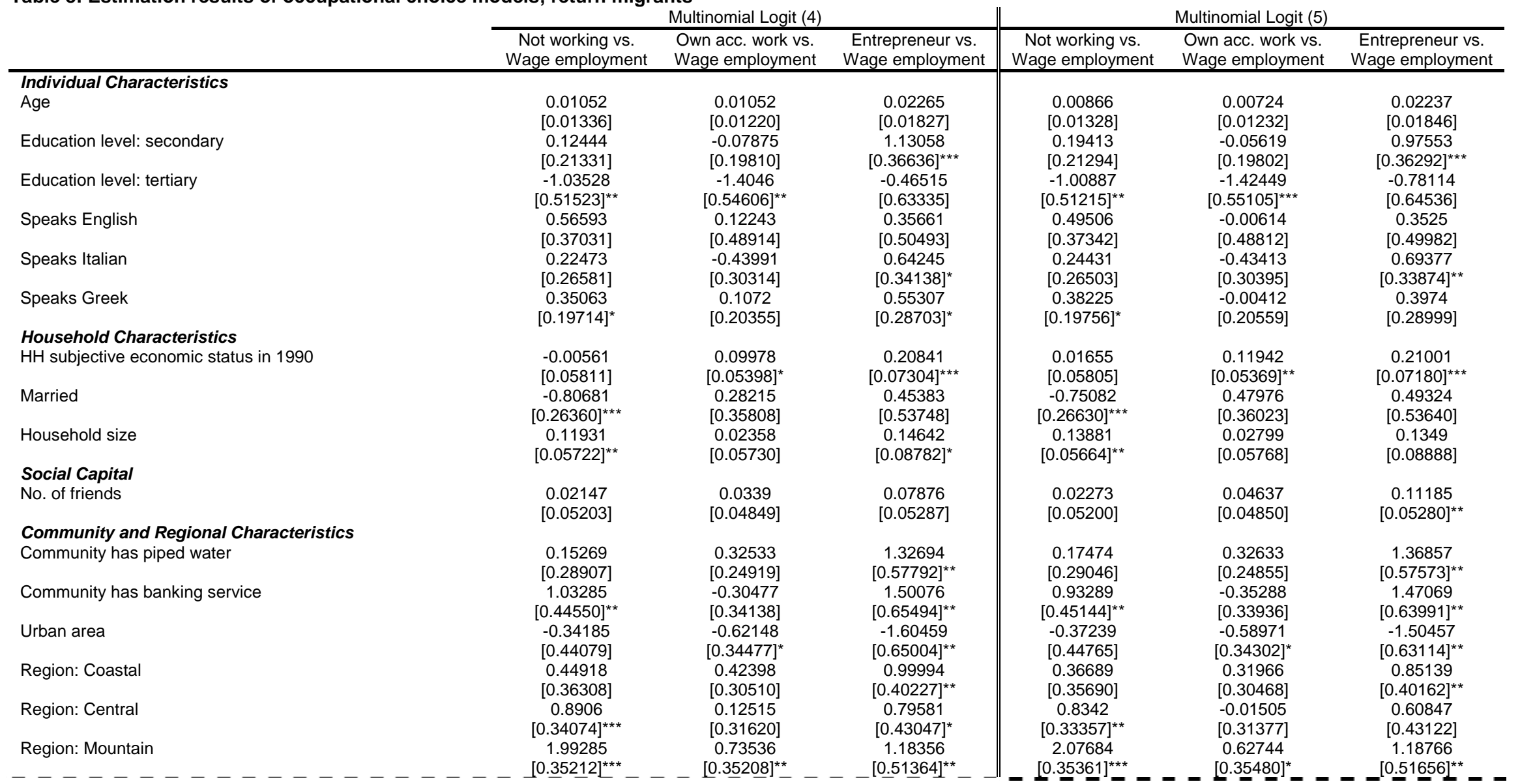


Table 8: Estimation results of occupational choice models; return migrants (continued)

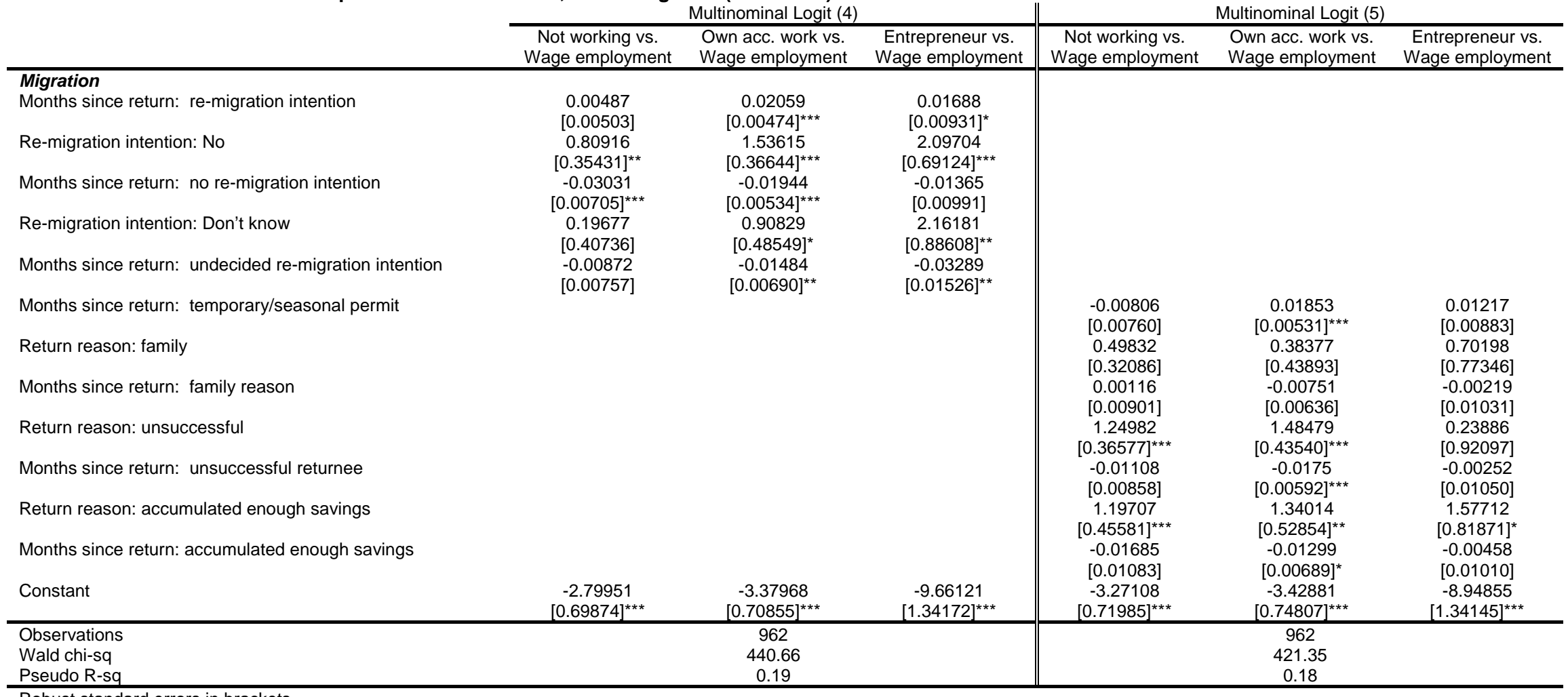

Robust standard errors in brackets

* significant at 10\%; ** significant at $5 \%$; *** significant at $1 \%$

Notes: The control group for the regional dummies is "Tirana", for re-migration intention dummies - "Re-migration intention: Yes"; and for the return reason dummies - "Return reason: temporary/seasonal permit". HH subjective economic status: 1=poor to 10=rich. 
Table 9: Odds ratios for occupational choice; re-migration intention of return migrants

\begin{tabular}{lccccc} 
& $\begin{array}{c}\text { Months since return: } \\
\text { intended re-migration }\end{array}$ & $\begin{array}{c}\text { Permanent return vs. } \\
\text { intended re-migration }\end{array}$ & $\begin{array}{c}\text { Months since return: } \\
\text { permanent return }\end{array}$ & $\begin{array}{c}\text { Not decided vs. intended } \\
\text { re-migration }\end{array}$ & $\begin{array}{c}\text { Months since return: not } \\
\text { decided }\end{array}$ \\
\cline { 2 - 7 } RW vs. RN & 1.00 & $0.45^{\star \star}$ & $1.03^{\star \star \star}$ & 0.82 & 1.01 \\
RO vs. RN & $1.02^{\star \star \star}$ & 2.07 & 1.01 & 2.04 & 0.99 \\
RO vs. RW & $1.02^{\star \star \star}$ & $4.65^{\star \star \star}$ & $0.98^{\star \star \star}$ & $1.48^{\star}$ & $0.99^{\star \star}$ \\
RE vs. RN & 1.01 & $3.63^{\star}$ & $0.14^{\star \star}$ & 0.98 \\
RE vs. RW & $1.02^{\star}$ & $8.14^{\star \star}$ & 0.99 & $8.69^{\star \star}$ & $0.97^{\star \star}$ \\
RE vs. RO & 1.00 & 1.75 & 1.01 & 3.50 & 0.98 \\
\hline
\end{tabular}

* significant at $10 \% ;{ }^{* *}$ significant at $5 \% ; * \star *$ significant at $1 \%$

Notes: Odds ratios computed after estimation in Table 7. RN, RW, RO, and RE stand for being a return migrant and not working, being a return migrant and working as wage employee, being a return migrant and working on own account, and being a return migrant and working as entrepreneur respectively.

Table 10: Odds ratios for occupational choice; return reasons of return migrants

\begin{tabular}{|c|c|c|c|c|c|c|c|}
\hline & $\begin{array}{l}\text { Months since } \\
\text { return: seasonal } \\
\text { migration }\end{array}$ & $\begin{array}{l}\text { Return out of } \\
\text { family reasons } \\
\text { vs. seasonal } \\
\text { migration }\end{array}$ & $\begin{array}{l}\text { Months since } \\
\text { return: family } \\
\text { reasons }\end{array}$ & $\begin{array}{l}\text { Failure of the } \\
\text { migration target } \\
\text { vs. seasonal } \\
\text { migration }\end{array}$ & $\begin{array}{l}\text { Months since } \\
\text { return: failure of } \\
\text { the migration } \\
\text { target }\end{array}$ & $\begin{array}{l}\text { Accumulated } \\
\text { enough savings } \\
\text { vs. seasonal } \\
\text { migration }\end{array}$ & $\begin{array}{l}\text { Months since } \\
\text { return: } \\
\text { accumulated } \\
\text { enough savings }\end{array}$ \\
\hline RW vs. RN & 1.01 & 0.61 & 1.00 & $0.29^{\star \star \star}$ & 1.01 & $0.30^{\star \star \star}$ & 1.02 \\
\hline RO vs. RN & $1.03^{\star \star \star}$ & 0.89 & 0.99 & 1.26 & 0.99 & 1.15 & 1.00 \\
\hline RO vs. RW & $1.02^{\star \star \star}$ & 1.47 & 0.99 & $4.41^{\star \star \star}$ & $0.98^{\star \star \star}$ & $3.82^{\star *}$ & $0.99^{*}$ \\
\hline RE vs. RN & $1.02^{*}$ & 1.23 & 1.00 & 0.36 & 1.01 & 1.46 & 1.01 \\
\hline RE vs. RW & 1.01 & 2.02 & 1.00 & 1.27 & 1.00 & $4.84^{*}$ & 1.00 \\
\hline RE vs. RO & 0.99 & 1.37 & 1.01 & 0.29 & 1.02 & 1.27 & 1.01 \\
\hline
\end{tabular}

Notes: Odds ratios computed after estimation in Table 7. RN, RW, RO, and RE stand for being a return migrant and not working, being a return migrant and working as wage employee, being a return migrant and working on own account, and being a return migrant and working as entrepreneur respectively. 
Table 11: Differences between predicted probabilities and counterfactuals

\begin{tabular}{|c|c|c|c|}
\hline & $\begin{array}{l}\text { Predicted } \\
\text { probability }\end{array}$ & Counterfactual & Difference \\
\hline & Return migrants & $\begin{array}{c}\text { Return migrants - } \\
\text { had they not } \\
\text { migrated }\end{array}$ & \\
\hline Occupation: not working & 0.211 & 0.159 & $0.053^{\star \star \star}$ \\
\hline Occupation: wage employee & 0.515 & 0.560 & $-0.046^{* * *}$ \\
\hline Occupation: own account worker & 0.195 & 0.236 & $-0.040^{* * *}$ \\
\hline \multirow[t]{2}{*}{ Occupation: entrepreneur } & 0.079 & 0.045 & $0.034^{\star \star \star}$ \\
\hline & $\begin{array}{c}\text { Return migrants } \\
\text { (only those } \\
\text { back in Albania } \\
\text { for } 12 \text { months } \\
\text { or more) }\end{array}$ & $\begin{array}{c}\text { Return migrants } \\
\text { (only those back in } \\
\text { Albania for } 12 \\
\text { months or more) - } \\
\text { had they not } \\
\text { migrated }\end{array}$ & \\
\hline Occupation: not working & 0.127 & 0.130 & -0.003 \\
\hline Occupation: wage employee & 0.503 & 0.593 & $-0.090 * \star \star *$ \\
\hline Occupation: own account worker & 0.258 & 0.224 & $0.033^{\star \star \star}$ \\
\hline \multirow[t]{2}{*}{ Occupation: entrepreneur } & 0.112 & 0.052 & $0.059 * * *$ \\
\hline & Non-migrants & $\begin{array}{c}\text { Return migrants - } \\
\text { had they not } \\
\text { migrated }\end{array}$ & \\
\hline Occupation: not working & 0.153 & 0.159 & -0.005 \\
\hline Occupation: wage employee & 0.570 & 0.560 & 0.009 \\
\hline Occupation: own account worker & 0.223 & 0.236 & $-0.013^{\star \star}$ \\
\hline \multirow[t]{2}{*}{ Occupation: entrepreneur } & 0.054 & 0.045 & $0.009 * * \star$ \\
\hline & Non-migrants & $\begin{array}{c}\text { Non-migrants - had } \\
\text { they migrated and } \\
\text { returned }\end{array}$ & \\
\hline Occupation: not working & 0.153 & 0.172 & $-0.019^{\star \star \star}$ \\
\hline Occupation: wage employee & 0.570 & 0.538 & $0.031^{\star \star \star}$ \\
\hline Occupation: own account worker & 0.223 & 0.215 & $0.008^{\star * *}$ \\
\hline Occupation: entrepreneur & 0.054 & 0.075 & $-0.021^{\star \star \star}$ \\
\hline \multicolumn{4}{|c|}{${ }^{*}$ significant at $10 \% ;{ }^{\star *}$ significant at $5 \% ;{ }^{\star * \star}$ significant at $1 \%$} \\
\hline Notes: The counterfactual va & 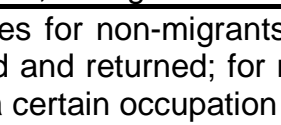 & ving tav & bein \\
\hline
\end{tabular}

